\title{
Family, Peer and School Influence on Children's Social Development
}

\author{
Ines Blažević ${ }^{1, *}$ \\ ${ }^{1}$ Education and Teacher Training Agency, Croatia \\ *Correspondence: Education and Teacher Training Agency, Tolstojeva 32, 21000 Split, Croatia. Tel: \\ 385-91-1570-236. E-mail: iblazevic@ffst.hr
}

Received: February 8, 2016

Accepted: March 10, 2016 Online Published: March 28, 2016

doi:10.5430/wje.v6n2p42

URL: http://dx.doi.org/10.5430/wje.v6n2p42

\begin{abstract}
Theory of origins of the paper starts from holistic and humanistic approach to upbringing and education, which has a goal of comprehensive development of student. An integral children's development can be encouraged by thoughtful planning of school activities in the school curriculum. Co-creators of the school curriculum (teachers, students and parents) need to create different school activities that will give a chance to the students to express their knowledge, skills and capabilities, and to develop socially as well. In the period of middle childhood there is a special importance is of the social development because the first friendships are made than, strengthens the influence of the school at the social development, and the influence of the family is still present there.

In order to understand better the children's social development the paper will display the theories of social development and the research results of the influences on social development of the student. Understanding of the family, school and peer influences on the social development of the student is of an extreme importance as a starting point for creating school activities that would encourage not only social but also integral development of the students.
\end{abstract}

Keywords: family; school; peer; school curriculum; children's social development

\section{Introduction}

The role of the school is to stimulate student's integral development within three domains of knowledge: affective, cognitive and psychomotor. It is expected from the teachers to equally stimulate all student's capabilities (Mijatović, 1999) and to observe the student as a human and social being (Previšić, 1999). In accordance with the above, more and more classes are being affirmed that are oriented to the child (Walsh, 1997) as well as pro-social classes (Čudina-Obradović, Težak, 1995) that encourage social learning as a part of overall learning. Children's social development, which represents the development of capabilities of understanding social relations and suitable psychosocial functioning, includes behaviour, attitudes and affects united into children's interaction with adults and peers (Brajša-Žganec, 2003). Numerous researches that were involved into children's social development indicate to positive influence of teachers, parents and peers on the social development of the students (Đorđević, 1981, Allen, Weissberg \& Hawkins, 1989, Lacković-Grgin, 1990; Ladd, 1999; Buljubašić-Kuzmanović, 2008, Buljubašić-Kuzmanović \& Livazović, 2010) emphasising how socially developed child acquires good developing results that enable satisfying and competent participation in the community that they belong to (Katz \& McClellan, 1997, Raver \& Zigler, 1997; Rose-Krasnor, 1997; according to Brajša-Žganec, 2003). Katz and McClellan (1997) emphasise that the community is the basis for creation of a context of social development, and the communities could be families, school and peer groups.

In the period of middle childhood, the influence of family, teachers and peers is of an extreme importance (Vizek-Vidović, 2003). The results showed that the children that created a relationship of trust with teachers are more socially competent in the relationships with the peers (Klarin, 2006), and it is especially emphasised the importance of emotional literacy of parents on social development of the students and the quality of adjustment (Buljubašić-Kuzmanović, 2007). The school has a role to prepare the student for the future profession, but also to work in the community (Rychen \& Salgnik, 2003; ten Dam \& Volman, 2007). The teachers need to have an educative effect, encourage students to work in groups, and to base their classes on interaction, partnership and cooperation (Buljubašić-Kuzmanović, 2012). The school as the community of upbringing into the centre of the 
educational process sets the students and their integral development, and to the social development, as a significant factor of growing up and success, attaches a special attention (Buljubašić-Kuzmanović, 2012). In order to contribute to better student's social development, the teachers need to know theories of social development well. Knowing the theories of the social development, they can create, with more quality, the school activities that will stimulate children's social development, as well as the integral development in general.

\section{Theoretical Views of the Children's Social Development}

When we analyse children's social development and the influence of the family, peer and school on them it is important to know the basics of the theory of the social development. Some of the theories emphasise the importance of the family for the student's social development, while the others emphasise the influence of the child's social environment. The theory of commitment of the theorist John Bowbly emphasises the importance of early relationship with parents (guardians) in child's development and great influence on social relationships in the whole life (Bowbly, 1969). Ainsworth, Blehar, Waters \& Wall (1978) discovered that children that are tightly connected to their mothers as babies have a tendency to develop stronger self-respect and better self-confidence, to be independent, better in school, have successful social relationships and experience less depression and anxiety. Schaffer and Emerson (1964) based on researches concluded that children that grew up in orphanages can also manage to develop a feeling of trust, but it is then important factor of a care quality. When guardians react fast and prompt, children learn to rely on people who are responsible for their care, and in contrary, the children that do not gain a trust early in their life can have a negative influence in a later childhood and during the life when different types of behaviour disorder appear. The aforementioned cognitions indicate to the importance of the cooperation between the family and school in order to help the students in proper social development by appropriate support.

The theory of social learning of Albert Bandura emphasises the importance of influences of the environment on the social development of students according which the children learn new behaviours by observing other people, including parents, teachers and peers, and on that way, they develop new skills and acquire new information (Bandura, 1977). A characteristic of this learning is to happen spontaneously and it requires existence of a model apropos person (parents, friends, media persons,..) whose behaviour represents the base of the learning. In the period of the middle childhood, it is very important in school context for teachers whose model of behaviour the students accept fast due to strong socio-emotional relations that theachers have with their students, and time that they spend together with them on daily basis. Supervising the teachers and their social actions, the student will according to a model create social contacts and in that way socially develop.

Socio-cultural theory of Lev Vygotsky belongs to the early theories of social constructivism according which for the development of more cognitive functions social environment in which the child acquires experiences is important. Vygotsky emphasises the importance of cognitive processes for children's social behaviour and social interactions, wherein the child learns new social and cognitive skills through interactions with adults and elder children (Brajša-Žganec, 2003). Early socialisation patterns, acquired in the family influence the future quality of the relationships with the other people (Bowlby, 1975; Maccoby, 1980; Schaffer, 1964, 2000; Vander-Zander, 1993). Vygotsky's theory also promotes a context of learning in which students play a main role in learning, but not transmission model in which the teacher "transmits" information. Vygotsky (1978) emphasises that an individual cannot maintain in full his/her potentials without help from others, and peer relations observes in a context of facilitating learning through experiences mediated by other people. Therefore, it is of an extreme importance that the teacher provides to the students stimulating social environment in which they will be able to exchange their experiences with their peers and to develop socially.

Bronfenbrenner ecological theory (1979) emphasises the importance of the environment for children's social development (Vasta, 1998). Within the ecological theory of development, he identified four levels of environmental influences on child: Microsystems (family, kindergarten, school), Mesosystem (mutual action of different Microsystems), Exosystem (wider environment) and Macrosystem (features of certain culture: education, religion, social system) (Brajša-Žganec, 2003). Paquette and Ryan (2001) analysing ecological theory suggest that the child is in the centre of the system, while the layers of the environment are getting wider around him/her in concentrated circles, and they stronger and weaker influence on his/her development. Bronfenbrenner also underlines that overall context in which the children's development is carried out importantly influences the course of development and development outcomes, and without neglecting individual features of the child and believes that the development is a result of interaction of child's features and environment in which the child grows (Bronfenbrenner \& Ceci, 1994). In the context of this theory, it is important to influence on children's social development with potential social 
interactions by social environment, but without neglecting his personal development.

Erikson's theory of psychosocial development (1950) worries about our everyday action in social world and wants to explain and understand how an individual overcomes everyday requirements of the social life, especially personal relationships and our attitudes towards the society (Pennington, 1997). Basic feature of this theory is development of ego-identity (part of our psychological structure that we believe is "I") through series of internal and external conflicts or crisis. Erikson assumes that ego goes through eight stages of development so called "eight man's stages". At each stage an individual needs to overcome some "crisis" from which an attitude is developed towards oneself and other people. At the fourth stage of development, in age of early and middle childhood, he emphasises psychological aspect of crisis in a sense of diligence versus inferiority. In this age, the child tries to overcome all tasks that are given to him/her, and if in the previous stage the initiative has developed then it will greatly help $\mathrm{him} / \mathrm{her}$ in this developmental age. Because of it, it is extremely important for his/her optimal development to provide enjoyment and mastering of developmental tasks in school and out (experience of success and progress). Not only parents (guardians) need to be aware of the mentioned but also child's close environment and especially the teachers because they together represent the important persons in child's life in this age. The teacher should, therefore need, though class work with children, create as much as possible opportunities that with team work the students create friendly relationships with peers and on that way to learn about different social skills, but also to self assessment as an important element of child's successful development.

When we speak about social development, it is also important to mention the theory of cognitive development of Jean Piaget that emphasises how children cannot achieve maximal possible degree of cognitive development without exposing to stimulating experiences in the social environment (Piaget, 1987). With his theory, known as socio-constructivist, he emphasised that the construction of knowledge happens during the interaction with social environment and active actions of the child. The implications of the Piaget's theory for education are visible in a change of a role of the teacher that does not have to be the transmitter of the knowledge but moderator and creator of the conditions for acquiring knowledge of the students. During such organisation of the classes, it is important that the teacher, besides of ensuring the conditions for acquiring knowledge of the students, needs also to provide conditions for the social development of the student.

\section{Social Development in the Middle Childhood}

In the period of the middle childhood extremely important is social development, which represents the development related to the development of child's capability of understanding of social relations and suitable psychosocial functioning (Brajša-Žganec, 2003). Even though in this development period the children spend less time with family, the influence of the family is not decreased (Klarin, 2002). The parents represent to the child a model, as in behaviour also for attitudes and the parents provide them the feeling of being a shield of their immediate environment, permanent feeling that they are worried, cherished and protected (Buljubašić-Kuzmanović, 2012). Starting the school an important leap in the development of social relations simultaneously occurs because the child from simple and familiar situation of family, where he/she was protected and privileged often, passes into new, complicated and unpredictable situation where he/she has to fight for his/her position in the big group of equal peers (Andrilović \& Čudina-Obradović, 1990).

The main features of the social development in the middle childhood are: forming of the first friendships, growth of self-respect, differentiation of capabilities, effort and happiness during the success and failure, regulating emotions, understanding of connection between moral regulations and social conventions, appearance of peer groups, mutual trust (Berk, 2008).

The middle childhood is developmental period of intensive social interactions where the first friendships are made. The interaction with the teacher also has a prominent role in forming of peer relations (Klarin, 2002), because the interaction with adults in this period creates with children the feeling of safety in forming relations with peers. In the period of the middle childhood, the groups of peers are not firm, and acceptances are easily changed and ceased. They are mostly consisted of children of the same sex and age, and the friendships are relatively superficial and oriented to mutual interests or participation into activates in which they enjoy. The boys get on a status if they are good sportsmen, brave, capable to attract the attention and friendly to other boys and they are more oriented to sports and other physical activities while the girls on activities that have more prominent social interaction. The girls at other girls value popularity, optimism, friendliness and sense of humour on their own expense. The friendships become more stabile, and they are based on mutual support, care, loyalty and mutual giving and taking. Non-acceptance by peers can have negative consequences, and mostly the children who are exposed to that are 
rejected, aggressive and withdrawn. Well-accepted and popular children are ready to help and cooperate, take care of others and have highly developed skills of pro-social behaviour and resolving the conflicts (Vizek-Vidović, Miljković, Rijavec \& Vlahović-Štetić, 2003).

In this period the feelings of self-determination (a right to decide on their own destiny) and self-respect develop (impression of person about himself/herself) (Coopersmith, 1967) that are extremely important as areas of personal and social development. Self-perception exists for different student's life areas: academic (opinion of the child about himself/herself as a student), social (opinion about himself/herself in relation to other people), emotionally (perception of own emotions) and physically (self-perception related to physical look and capabilities). Self-respect can be related to each specific part of self-perception for example the person can have high self-respect related to social self-perception, but low related to academic self-perception. In the period of the middle childhood, the children value themselves comparing them with their peers, but the change comes in the academic self-perception because present school system is oriented almost exclusively on cognitive aspect of education. It puts an accent on acquiring knowledge while affective and social components are mostly neglected, so that the valuing is conducted by valuing exclusively knowledge while other characteristics of the students are not being valued. It is important to know that the image about yourself is mostly under influence of family upbringing, and the important role in this have teachers as well (Čudina-Obradović \& Težak, 1995). Big number of researches show how students that have low self-respect, they accept less the responsibility for their school success, and do not see the relation between an effort and achieved success but attribute it to luck or teacher favouring (Marsh, 1984). Due to low self-respect, they do not trust into themselves and their opinion but they believe that others know better, so they easily conduce to peer pressure (Brockner, 1985). The students with high stage of credential into their own competences try to solve more tasks while the students that do not trust themselves give up from the tasks even before they try to solve it (Bezinović, 1988). While the students with lower family and school self-respect are more likely to delinquent behaviour, and easily give in under the group pressure. In this period of development, the children with their peers spend most of the time in school where they exercise the first proper friendships, and the school is exactly the place that through different planned activities of the school curriculum can contribute to better social development of children.

\section{Family Influence}

When we analyse family influence on children's social development it is important to observe it in context of upbringing styles of parenthood. The first social patterns of behaviour, positive or negative, which child uses in the interaction with peers are the outcomes of the social relations that the child acquired in the family and they are under direct influence of the educational styles of the parents. Berk (2008), the family styles of upbringing describes as a combination of parent's behaviour in different life situations based on which the permanent educational climate is created in the family. He emphasises four styles of parent's education:

- Authoritarian - Parents want to have everything under control and do not show any signs of love, attachment or warmth, and the consequence of such behaviour is that the children cannot develop high level of pro-social behaviour, but their behaviour is filled with aggression, quarrelsome, bad temper and self-destructiveness (Vasta, Haith \& Miller, 1998; Deković \& Janssens, 1992)

- Authoritative - The parents have caring, sensitive relation to the needs of the children with clear limits to the children. The result is the children's positive image about themselves and often they acquire high academic success (Klarin, 2006; Berk, 2008)

- Indifferent - The parents are emotionally withdrawn and distant from the children, indifferent towards children's behaviour, not interested in children's success. The result is neglect of the children and lack of supervision

- Indulgent - The parents towards children have warm and caring relation, but with too much pamper so that the children of such parents often are impulsive, irritable, without self-control and spoiled. The result can often be the cause of depression and anti-social behaviour (Susskind, 2005).

It is important to emphasise that the researches confirmed that the educational style of parents is connected to the level of development of pro-social behaviour (Deković \& Janssens, 1992) and influence the socio-metric status of the person (Deković \& Raboteg-Šarić, 1997). The children raised by authoritative educational style easer make friendships and they are well accepted in the groups, while the methods of education where the parents demonstrate the power through threats and punishments resulted with difficulties in peers' relations (Davidson, Welsh \& Bierman, 2006). The authoritative educational style is the most desirable style in the social context because it provides the 
biggest opportunities for the development of children's self-confidence and independence with certain limits (Rueter \& Conger, 1998).

Steinberg \& Silk (2002) also emphasise how in the families with open communication in between the members, the children are developed that have desirable social skills and capabilities in solving problems. The researches indicate how parents' warmth and participation of parents make children liable to parents' influence and that enables more efficient socialisation (Darling \& Steinber, 1993). The researches on emotional literacy of parents (Shapiro, 1998; Buljubašić-Kuzmanović, 2007) which confirmed its influence on student's behaviour are particularly interesting, but they are significant for further researches that would give more precise answer on this complex family influence (Shapiro, 1998; Buljubašić-Kuzmanović, 2007). All aforementioned displays of the results of researches demonstrate in favour of family importance in providing sense of stability and connection in the family system in which the children can develop. And it serves them as starting point in the researches of social world (Henry and co., 1996) as well as in the direct connection of the relation quality between children and parents and social children's success (Ladd, Pettit, 2002).

\section{Peer Influence}

The peers groups are defined as social groups that are made of people with similar age, education or social status and which are primarily consisted of persons that share similar or same status and mostly they are almost the same age. (Lackovi -Grgin, 2006). Based on the researches of peers groups many scientists (Meada, Freud, Erikson, Piaget J), imply to important the peer influence on the social development (Ladd, 1999). The researches of the peer groups show how peer game has very important role in the socialisation (Cowen 1973 \& Roff and Sell, 1967), but also that bad peer relation in the childhood results to later social unacceptable behaviours. Bukowski and Hoze (1989) develop a model of the peer relations through two basic dimensions of social functioning of persons that are in a way a mirror of children's social competences: popularity and friendship. The popularity represents a perception of the person from the environment with high stage of acceptance, and the friendship as a two-way relation between two people filled with warmth and trust. With the friendship, a person satisfies the need for belonging through acceptance or desirability in the group, as well as the need for closeness that satisfies through friendly relations (Asher, 1996). In the literature, we can find several divisions of acceptance/rejection of children considering stage of preferences, and Coie (1984, according to Klarin, 2006) differ: popular, rejected, neglected, controversy and average child. Categories of rejected, isolated and neglected child belong to the category of unpopular children. The unpopular children are often more hyperactive, aggressive, egoistic and focused on themselves, overestimate their capabilities, neglecting the needs of others, lonely, shy, and rejection often appears as an important predictor of satisfaction with school, social self-respect, school achievements and perception of social support (Klarin, 2006). The pedagogy, all aforementioned connotations and labelling of children, does not accept. It considers them more as SOS signals of the children that cry for help, care and concern, but also for love, and an opportunity for an educational action. The category of the popular child and the child "a star" belong to the category of the popular children that are characterised with friendliness, communicativeness, sense of humour, high self-respect and cheerful mood. Simel, Špoljarić \& Buljubašić-Kuzmanić (2010) allege that popular children more often have close friend then the children that are not popular because they have more opportunities to make friendships. In addition, they allege that there is at least partial connection between popularity and friendship apropos how a weak peer acceptance does not necessarily result inadequate friendships. All mentioned speaks in favour of importance of peer groups, and especially in the age of middle childhood when the first friendship starts. In this period, the children are ready for cooperation and agreement, the friendship is observed as the relation of tolerance, trust and cooperation, and intimacy between the friends becomes an important feature of friendly relations.

\section{School Influence}

The importance of today's school is reflected in a sense that the school should be a community of growing up in which students feel successful and satisfied. The school needs to be the place where they can show their knowledge, skills and capabilities, non-violently solve conflicts, learn in an interesting and creative way, develop cooperation and more successfully relations with others, to be more tolerant, and to use acquired knowledge and experiences in everyday life (Buljubašić-Kuzmanović, 2012). As school could with its influence benefit to the social development of the students Buljubašić -Kuzmanović (2008) mention necessary interventions in the school itself and it is the practicing of the empathy and exercises of compassion, enabling all students to feel welcomed, accepted and respected. It is also important to encourage the development of real expectations for each student along with necessary adjustment, conversation about a role of failures in the process of learning and learning how to learn. It is 
essential to develop the responsibility and proper relation towards yourself and others, teaching the students solving the problems and bringing the decisions, changing of negative, static school scenarios with developmental and active, encouraging an active learning and self-evaluation, using of educational procedures that promote self-discipline. Katz \& McClellan (1997) emphasise the importance of the class in which the teacher does not only lecture the class content, in which it is not done only frontally in a traditional way but leaves the space for interpersonal communication between students. The school that is needed today is the school that encourages overall development of the students, respects diversity, and encourages individualisation and socialisation of the classes. In the school, the student has to, with an active role, acquire knowledge and develop creativity, and teacher needs to encourage social sensitiveness and partnership between the parents and the school. We need the school as a modern institution that is, besides acquiring knowledge, oriented to the development of the student's personality and his/her individuality as a complete young person that is an equal member of the social community (Previšić, 1999). However, the school today is perceived as the institution closed for innovations and creativity, without a spirit of unity, where a talent is not used as an advantage, and empathy, expression and understanding of your own feelings, self-control, independence, adaptability, popularity, capability of solving problems with others, persistence and friendly behaviour are not the priorities of education and upbringing. The school organised in such a way cannot attract today's youth and actively respond to their needs and expectations (Buljubašić-Kuzmanović, 2010). In addition, in the previous years, there are more and more emphases on partnership between the school and parents as a relevant factor of social development of the children so in resent years there is more and more talk about construction of a model of educational partnership with parents (Maleš, 2004; Jurčić, 2012). The model implies to the need of change of the parents and teachers' roles that will promote, facilitate and lead critical and self-directing process of teaching and the social development of the students. As they could take over this role, a specific pedagogy of upgrading is necessary that will improve its theoretical and practical knowledge, both parents and teachers. Still there is a traditional understanding of upbringing and education of the children that suggests separation of fostering of sense of self-worth, resistance and safety from learning basic school skills. However, the modern pedagogic paradigm is based on premises that the children's self-respect, competence and resistance will grow when they truly experience achievements in the school and at home, when they truly start to enjoy in learning and learn on their successes (Buljubašić-Kuzmanović, 2008).

\section{Conclusion}

By analysing the children's social development and the theories of the social development, it is evident how the children's social development is under the influence of the family, peers and school, especially in the period of middle childhood. In the period of the middle childhood, influence of the family is still present even though the influences of the school and peer are involved when they start the school. The family by its support and cooperation with the school can help with right social development of the students. Their mutual cooperation in particular can be manifested during the creation of school activities that will encourage social interactions between children. Especially important role is a role of the teacher in the creation of the classes that need to be enriched with activities that encourage the cooperation and mutual respect between the children. The classes that encourage the social development need to be lead by humanistic and holistic approach encouraging the quality social relationships. It is of great importance the influence of the peers on the social development in the period of middle childhood because it is the period of creating the first friendships. Considering the aforementioned, it is more and more necessary to encourage interaction-communicational education related to the interpersonal relations, the quality interaction and communication as well as readiness for the cooperation.

By researching the children's social development in the middle childhood, Santrock (1999) alleges how it is important for the encouraging socio-emotional development of the child to adjust to child's developmental needs. Furthermore, he alleges the necessity of encouraging peer interaction, enhancing social skills and positive social relations in the school. He emphases the importance of the school, as it is the place that stimulates the development of positive characteristics of child's personality, self-respect, emotional intelligence and modelling of pro-social behaviour. The school is expected that in the co-creation of the school curriculum puts students in the center and their integral development, multisource and multidimensionality of didactic-methodological design of the classes. The classes should be enriched with variety of teaching methods, procedures and social forms of work, which will contribute to the social interactions and the quality of children's social development.

\section{References}

Ainsworth, M. D. S., Blehar, M. C., Waters, E., \& Wall, S. (1978). Patterns of attachment: A psychological study of the strange situation. Hillsdale, NJ: Erlbaum. 
Allen, J. P., Weissberg, R. P., \& Hawkins, J. A. (1989). The Relation Between Values and Social Competence in Early Adolescence. Developmental psychology, 25(3), 458-464. http://dx.doi.org/10.1037/0012-1649.25.3.458

Andrilović, V., \& Čudina, M. (1990). Osnove opće i razvojne psihologije. Zagreb: Školska knjiga.

Asher, S. R., \& Rose, A. J. (1996). Promoting children's social-emotional adjustment with peers. In. P. Salovey \& D. J. Sluyter (Ed.), Emotional development and emotional intelligence: Educational implications (196 - 224). New York: Basic Books.

Bandura, A. (1977). Social Learning Theory. New York: General Learning Press.

Berk, E. L. (2008). Psihologija cjeloživotnog razvoja. Jastrebarsko: Naklada slap.

Bezinović, P (1988). Samopercepcija osobne kompetentnosti kao dimenzija vrednovanja vlastitog ja. Doctoral thesis. Rijeka: Filozofski fakultet

Bowlby J. (1969). Attachment. Attachment and loss: Vol. 1. Loss. New York: Basic Books.

Bowlby J. (1975). Bindung: Eine Analyse der Mutter-Kind-Bezieung. Muenchen:Kinder Verlag.

Brajša-Žganec, A. (2003). Dijete i obitelj: emocionalni i socijalni razvoj. Jastrebarsko: Naklada Slap.

Bronfenbrenner, U. (1979). The ecology og human development: Experiments by nature and design. Cambridge, MA: Harvard University Press.

Bronfenbrenner, U., \& Ceci, J. (1994). Nature - nurture reconceptualized in development perspective: A bioecological model. Psychological Review, 101(4), 568-586. http://dx.doi.org/10.1037/0033-295X.101.4.568

Bukowski, W. M., \& Hoza, B. (1989). Popularity and friendship- Issues in theory, measurement, and outcome. In Berndt, T. J., \& Ladd, G. W. (Ed.), Peer relationships in child development. New York: John Wiley \& Sons, $15-45$.

Buljubašić-Kuzmanović, V. (2007). Simptomi nasilja kod djece i emocionalna pismenost roditelja. Zagreb: Napredak, 148(1), 23-26.

Buljubašić-Kuzmanović, V. (2008). Odnos socijalne kompetencije i ponašanja učenika. Doctoral thesis. Zagreb: Filozofski fakultet.

Buljubašić-Kuzmanović, V. (2010). Socijalna kompetencija i vršnjački odnosi u školi. Pedagogijska istraživanja, 7(2), 191-203.

Buljubašić-Kuzmanović, V. (2012). Škola kao zajednica odrastanja. Pedagogijska istraživanja, 9(1-2), 43-57.

Buljubašić-Kuzmanović, V., \& Livazović, G. (2010). Odnos dječje socijalne i interkulturalne kompetencije. Split: Školski vjesnik, 59(2), 261-276.

Buljubašić-Kuzmanović, V., Simel, S., \& Špoljarić, I. (2010). Odnos između popularnosti i prijateljstva. Život $i$ škola, 23(1), 91-108.

Coopersmith, S. (1967). The antecedents of self-esteem. San Francisco: W. H. Freeman \& Co.

Čudina-Obradović, M., \& Težak, D. (1995). Mirotvorni razred. Zagreb: Znamen.

Darling, N., \& Steinberg, L. (1993). Parenting style as context: An integrative model. Psychological Bulletin, 113(3), 487-496. http://dx.doi.org/10.1037/0033-2909.113.3.487

Davidson T. A. M., Welsh, J., \& Bierman, K. (2006). Social competence: An entry from Thomson Gale's Gale Encyclopedia of Children's Health: Infancy through Adolescence. Thomson Gale.

Deković, M., \& Janssens, J. (1992). Parent's Child-Rearing Style and Child's Sociometric Status. Developmental Psychology, 28(5), 925-932. http://dx.doi.org/10.1037/0012-1649.28.5.925

Deković, M., \& Raboteg-Šarić, Z. (1997). Roditeljski odgojni postupci i odnosi adolescenata s vršnjacima. Društvena istraživanja, 4-5, 427-447.

Đorđević, D. (1981). Razvojna psihologija. Gornji Milanovac: Dječje novine.

Henry, C. S. (1996). Adolescent's Perception of Family System Characteristics, Parent-Adolescent Dyadic Behaviors, Adolescent Qualities and Adolescent Empaty. Family Relations, 45, 283-292. http://dx.doi.org/10.2307/585500

Jurčić, M. (2012). Pedagoške kompetencije suvremenog učitelja. Zagreb: Recedo.

Katz, L. G., \& McClellan, D. E. (1997). Fostering children's social competence. Washington: National Association for the Education of Young Children.

Katz, L. G., \& McClellan, D. E. (1999). Poticanje razvoja dječje socijalne kompetencije. Zagreb: Educa. 
Klarin, M. (2002). Razvoj u socijalnom kontekstu. Zbornik Učiteljske akademije u Zagrebu, 4(1), 167-175.

Klarin, M. (2006). Razvoj djece u socijalnom kontekstu. Zagreb: Naklada Slap.

Lacković-Grgin, K. (1990). Sociometrijski položaj i samopoštovanje kod djece osnovnoškolske dobi. Zadar: Radovi FF u Zadru, 29(6), 135-142.

Lacković-Grgin, K. (2006). Psihologija adolescencije. Zagreb: Naklada Slap.

Ladd, G. W. (1999). Peer relationships and social competense during early and middle childhood. Annual Review of Psychology, 50, 333-359.

Ladd, G. W., \& Pettit, G. S. (2002). Parenting and the development of children's peer relations. U: Bornstein, M. H. (Ed.), Handbook of parenting, vol 5, Practical issues in parenting, Mahwah, NJ: Lawrence Erlbaum, 269-309. http://dx.doi.org/10.1146/annurev.psych.50.1.333

Maccoby, E. E. (1980). Social development: Psychological growth and the parent-child relationship. New York: Harcourt Brace Jovanovich, Inc.

Maleš, D. (2004). Roditelji i učitelji zajedno. U: Vrgoč. H. (Ed.), Strategija odgojnog rada razrednika (zbornik radova). Zagreb: HPKZ

Marsh (1984). Making Students' Evaluations of Teaching Effectiveness Effective The Critical Issues of Validity, Bias, and Utility Herbert W. Marsh and Lawrence A. Roche University of Western Sydney, Macarthur, November 1997. American Psychologist Copyright 1997 by the American Psychological Association, 52(11), 1187-1197.

Mijatović, A. (1999). Ishodišta i odredišta suvremene pedagogije. U: Mijatović, A. (Ed.), Osnove suvremene pedagogije. Zagreb: Hrvatski pedagoško-književni zbor, 13-39.

Paquette, D., \& Ryan, J. (2001). Bronfenbrenner's Ecological Systems Theory. Retrieved from http://pt3.nl.edu/paquetteryanwebquest.pdf

Pennington, D. (1997). Osnove socijalne psihologije. Jastrebarsko: Naklada Slap.

Piaget, J. (1987). Intelektualni razvoj djeteta. Beograd: Zavod za udžbenike i nastavna sredstva.

Previšić, V. (1999). Škola budućnosti: humana, stvaralačka i socijalna zajednica. Napredak, 140(1), 7 - 16.

Rueter, M. A., \& Conger, R. D. (1998). Reciprocal influences between parenting and adolescent problem solving behavior. Developmental Psychology, 34, 1470-1482. http://dx.doi.org/10.1037/0012-1649.34.6.1470

Rychen, D. S., \& Salganik, L.H. (2003). Competencies for successful Life and Well-Functioning Society. Cambridge: Hogrefe Publishing GmbH.

Santrock, J. W. (1999). Life - span development. Boston: McGraw HillCollage.

Schaffer, H. R. (2000). Social development. Oxford: Blackwell Publishers Inc.

Schaffer, H. R., \& Emerson, P. E. (1964). The development of social attachments in infancy. Monographs of the Society for Research in Child Development, 29, 94. http://dx.doi.org/10.2307/1165727

Shapiro, L., E. (1998). Kako razviti emocionalnu inteligenciju djece. Zagreb: Mozaik knjiga.

Steinberg L., \& Silk J. S. (2002). Parenting adolescents. U: Bornstein M. H. (Ed.), Handbook of parenting: Vol. 1: Children and parenting. Mahwah, NJ: Lawrence Erlbaum Associates, 103 - 133.

Susskind, J. (2005). Social Development. Encyclopedia of Human Development. SAGE Publication.

ten Dam, G., \& Volman, M. (2007). Educating for Adulthood or for Citizenship: social competence as an educational goal. Retrieved from http://dare.uva.nl/document/139133

Vander-Zanden, J. W. (1993). Human development (5th ed.). New York: McGraw-Hill.

Vasta, R. (1998). Dječja psihologinja. Jastrebarsko: Naklada Slap.

Vizek-Vidović, V., Miljković, M., Rijavec, M., \& Vlahović-Štetić, V. (2003). Psihologija obrazovanja. Zagreb: IEP, d.o.o..

Vygotsky, L.S. (1978). Mind and society: The development of higher mental processes. Cambridge, MA: Harvard University Press.

Walsh, B. (1997). Stvaranje razreda usmjerenih na dijete. Projekt korak po korak: Otvoreno društvo Hrvatska. 